$\xi=-1$

\title{
Employment Protection Through the Perspective of Fulfilling Citizens' Rights in Indonesia
}

\author{
Nuridin, $\mathrm{SH}, \mathrm{MH}^{1 *}$, Sanusi, $\mathrm{SH}, \mathrm{MH}^{2}$, Tiyas Vika Widyastuti, $\mathrm{SH}, \mathrm{MH}^{3}$ \\ ${ }^{1,2,3}$ Lecturers of Law Faculty at Universitas Pancasakti Tegal-Indonesia \\ *Corresponding author E-mail: nuridin.fhupstegal@gmail.com
}

\begin{abstract}
Outsourcing system is a prevalent form of employee recruitment in Indonesia. The Employment Relationship of Outsourcing System under the provisions of Law Number 23 of 2003 concerning Employment so far has not been able to deliver welfare for workers/ labors, in return for their contribution to the companies' productivity improvement. Labors do not obtain their rights which have been warranted in the Law. Additionally, outsourcing system has created uncertainty in employment relationship. This research uses the paradigm of constructivism and selected macro and micro theories to analyze the problems surrounding employment protection. We also employ qualitative method with a socio-legal approach. Our contention is that a change is critically needed to be made to the regulations of law which govern employment relationship or partial transfer of job to a third party. The change should reflect what the workers/ labors wish. It should also bear values such as justice and welfare for workers/ labors. This is all meant to achieve a harmonious and just employment relationship based on Pancasila (The Five Pillars of Indonesian State Ideology) and the Indonesian 1945 Constitutionn.
\end{abstract}

Keywords: Employment Law; Outsourcing; Human Rights; Indonesia

\section{Introduction}

According to (1), outsourcing has been a long standing practice for over two decades. (2) has further asserted:

"Despite the position that workers/ labors as one of the most important production factor in a company's production, from their bargaining position point of view, almost every country generally sees a constant increase in outsourcing practice from year to year. This has led to the need for policies capable of driving production growth aiming at absorbing more workforce." (p. 59-68)

The percentage of outsourcing workers/ labors used in middle and upper scale national and multinational companies in Indonesia is expected to reach $60 \%$ of the total needs for workers/labors this year. This percentage is predicted to keep increasing until it reaches $80 \%$ of the total need for workers/labors in the next year. Irham A Dilmy, Director of Manager Master Executive Program at Bina Nusantara, suggests that the use of outsourcing workers/labors by multiple companies increases $20 \%$ at average per year due to the demand and trend occuring in the global labor market (2006).

According to (3) in the research conducted by the Research Division of PPM Manajemen in 2015 to 60 companies in Indonesia (p. 5-6), 73\% of these companies are found using outsourcing workers/labors in their operation, while the remaining $27 \%$ do not use outsourcing workers/ labors. Out of this $73 \%$, those companies which fully employ outsourcing workers/ labors are engaged in banking, paper, education service, rubber and plastic processing and food and beverage industries. As for those engaged in heavy equipment, machinery and transportation means (automotive and spare parts), 57.14\% of their employees are outsourcing workers/ labors. Pharmaceutical and basic chemicals have $80 \%$, telecommunication and information technology $60 \%$, and other industries $50 \%$. These other industries consist of power generation maintenance service, consulting, EPC (enginering, procurement, construction), wood processing, healthcare, printing and publishing, and electronic industries. From the ownership status perspective, it is found that State-Owned Enterprises, Joint Ventures, and Non-profit Companies use 100\% outsourcing workers/ labors in their operation activities. National private companies use outsourcing workers/labors at $57.69 \%$ and foreign private companies use $85.71 \%$.

The use of outsourcing system is a unique trend. Companies try to save on their expense and costs in paying for the Human Resources working for them. This is because the economic state they are in does not allow them to give their workers/ labors a fixed, great amount of money, making them to resort to partially transfer their jobs to others using service supply or workers/labors procurement services. These outsourcing employees do not have many other choices since the open unemployment rate at national level have exceeeded 11.6 million people and disguised unemployment 30 million people from the job offers for more than 106.9 million people. Meanwhile, many companies are winding up due to their loss in competing with imported products, with decreased exports thanks to the high domestic production costs(4). So far, the practice of outsourcing system benefits the companies more through their production cost efficiency along with the absence of any allowance they need to give to their workers/ labors. Hojnik's study in Slovenia proves statistically that the reason for using outsourcing method is to reduce the costs (2010). Spencer's study in China and India also shows that international outsourcing has lower costs (2010). Due to the positive effect of the use of outsourcing, there has been a shift in the outsourcing nature. In the beginning, it was to support the company's supplementary activities. Nowadays, many companies outsource their production activities extensively(5). 
The application of outsourcing system has caused a change in the form of employment relationship pattern, particularly as can be found in major manufacturing industries. According to Imam Soepomo, employment relationship is a relationship between a worker/ labor and his/ her employer. Employment relationship shows the position of both parties which essentially depicts the employers' rights and duties to their workers/ labors (2001). Furthermore, it is also explained that employment relationship is in effect after an work agreement is made between workers/ labors and employers, i.e. an agreement where the first party, the worker/ labor, binds himself/ herself to work for certain amount of fee for the other party, the employer, who binds themselves to employ the workers/labors for a certain amount of fee. The relationship that exists between the workers/ labors \& outsourcing company and the principal (capital owner) is a dependence relationship. The type of dependence is somewhat imbalanced. According to (6), it is believed that the power centrally accumulated in the hand of employers or bourgeoisie in managing and controlling limited resources. In practice, this dependent relationship goes one-sided because of the capitalism principle they hold, i.e. maximizing profit by emphasizing efficiency and productivity, leading to the frequent exploitation of workers/ labors (p.10).

The employment relationship in outsourcing system as explained earlier above is so detrimental to workers/ labors since there is no employment relationship between the principal and the workers/ labors. Outsourcing contract makes workers/labors' bargaining position weaker before the principal. Workers/l abors in an outsourcing contract are merely objects of agreement and employment relationship exists only between the company supplying the workers/labors (vendor) and the workers/labors themselves. The responsibility for workers/ labors' job security becomes unclear, because the employers directly facing the workers/labors could blame the outsourcing company. It can be seen from the employment relationship which always takes the form of a contract (not permanent), with lower wage and minimum social security as well as absence of work protection and career development guarantee. Therefore, as asserted by (7), there is a need for a legal protection. According to (8), this protection constitutes workers/ labors' rights which are secured by the government, and when these rights are breached, certain legal consequences might occur (p. 2).

\section{Literature Review}

\subsection{The State's Responsibility in Fulfilling Citizen's Rights towards Worker Welfare}

The concept of welfare state aims at realizing people's welfare. A development of the role that the state plays has occured as a result of modernization and democratization process of state administration system (9), p.42). The failure of legal state results in a change in paradigm towards the state responsibility, from night-watchman state into welfare state. Jeremy Bentham's utilitarianism theory states that what is suitable to be used or what is suitable for individual is what tend to augment happiness. What is suitable for the society is what tends to augment the happiness of individuals who are members of that society. This is the starting point in managing human life, including the law(10). The law as a common order of life should directed to support the realization of the greatest happiness of mankind. The state plays a highly strategic role in realizing their citizen's happiness and welfare by implementing the state functions.

(11) has further asserted:

"Welfare state incorporate socialism elements, prioritizing welfare in both politic and economy. The welfare state contains such principles as liberty, right equality, and mutuality. The mutuality principle could be deemed equal as family or gotong royong (mutual cooperation)" (p. 160).
As (12) has elaborated (p. 3), the state's function in economic field includes: (1) the state as people's welfare guarantor; (2) the state as a regulator; (3) the state as an entrepreneur or the one running certain sectors through State-Owned Enterprises (BUMNs); and (4) the state as a referee to formulate a just standard regarding economic sector, particularly the state enterprises. The state's function in a welfare state is that it may intervene how its economy goes. In contrast to welfare state, a night-watchman state holds a view that the government should never intervene its economy. The main ideology of nightwatchman state is capitalism element.

After the World War ended, capitalists did not deem the governments as enemies anymore since they had their own new enemy they had to deal with, i.e. large companies which oppressed their competitors and labor unions which were getting stronger and arbitrarily used their "right to strike" as their weapon. Capitalists had then turned to the government, begging them to intervene the organization of business competition and labor relationship.

The state's roles and responsibilities to its citizen's welfare occur as a result of clash between the ideology predominantly followed by a society and the state ideology itself. Globalization, which began in the 15th century, was found to keep maintaining the role that liberal capitalists played to control certain states' economic system and even the world. An example of this is how western countries expanded their power to eastern countries in the form of imperialism.

According (13), World Bank and International Monetary Fund (IMF) are two worldwide financial organizations representing the true form of superpower country's imperialism which provides loan to poor countries in the world. Imperalism has turned into neo-imperalism, liberalisme has shown itself as a neo-liberalism. The neo-liberalism's ideology and prectice, combined with transnational companies' operation and international organizations, have made the state weaker as an actor in the world's economic system (p. 83). Such circumstance will have some influence on their policies regarding people's welfare.

It is a reflection of economic democracy which is a unique characteristic of Indonesia, even though in the history of Indonesian government development, the Indonesian Constitution had been amended several times. However, constitutionally speaking, as asserted by (14), it could be proven that Indonesia as a legal state follows the welfare state view (p.151-161). Indonesia is determined to stick to welfare state view. It is a belief where the state could use its law as one of its means to govern and organize as well as guaranteeing its people welfare. The national law system development will always be used to support the full responsibility of such decision.

\subsection{Protection of Workers/ Labors as Citizen in Indonesia's Constitution}

Protection of workers/ labors aims at ensuring that a harmonious employment relationship system could occurs. According to Soepomo (as cited in Karim, 2003), protection of workers/labors is divided into three, namely (a) economic protection, that is a protection of workers/labors in the form of sufficient earnings, including if workers/labors are unable to work beyond their willingness; (b) social protection, i.e. protection of workers/labors in the form of occupational health security, freedom of association and protection of rights to organizae and (c) technical protection, that is protection of workers/labors in the form of work security and safety. These three types of protection above definitely need to be understood and implemented as best as possible by entrepreneurs as employers (p. 34).

The arrangement of worker/ labor protection in Law Number 13 of 2003 includes: (1) protection of worker's basic rights to have a discussion with the company; (2) protection of work safety and health; (3) special protection for female, child, and disabled workers and (4) protection on worker/labor welfare and social 
security fee. Furthermore, Article 5 of Law Number 13 of 2003 also provides a protection that every worker/labor is entitled and has the equal chance to obtain feasible jobs and livelihoods without any discrimination against their sex, ethnic, race, religion, and political school of thought according to their respective interest and ability. Article 6 of Law Number 13 of 2003 requires entreprenuers to give their worker's rights and duties without any discrimination against their sex, ethnic, race, religion, skin color and political school of thought.

In Indonesian constitution, it is set forth in Article 27 paragraph (2) and Article $28 \mathrm{D}$ paragraph (2) of 1945 Constitution of the Republic of Indonesia. The formulation in Article 27 paragraph (2), that is the formulation which existed since the enactment of the 1945 Constitution of the Republic of Indonesia as the basic law in Indonesia, the provisions of Article 27 paragraph (2) read as follows: "Every citizen has the right for works and earnings feasible for humanity. Meanwhile, the formulation in Article $28 \mathrm{D}$ paragraph (2) is a result of second amendment of 1945 Indonesian Constitution."

According to (15) (p. 27), fundamentally speaking, Indonesian employment law should be based on two articles in 1945 Indonesian Constitution, namely Article 27 paragraph (2) and Article 33 paragraph (1) which set forth that the basis for Indonesia's economy is an economy grounded from the principles of family and economic democracy. Article $28 \mathrm{D}$ paragraph (2) reads "everyone is entitled to work for a just and feasible reward and treatment in an employment relationship".

Based on the provisions of Article $28 \mathrm{D}$ paragraph (2), the right to work is everyone's human rights, thus, it is appropriate to classify this article as a regulation which governs human rights issues. Based on the Universal Declaration of Human Rights Article 23 on the rights to work, i.e.:

(1) Everyone has the right for jobs, for free choice of jobs, for employment requirements over unemployment;

(2) Everyone with no discrimination whatsoever has the right of equitable wage for an equitable job;

(3) Everyone that is working has the right of fair and adequate reward which ensures that he/she and his/her family live a worthy life according to mankind dignity and, when necessary, with other ways of social protection; and

(4) Everyone has the right to form and join a labor union in order to protect his/her interests.

\subsection{The Urgency of Harmonious, Dynamic and Just Employment Relationship in Indonesia to Fulfill Citizen Rights}

In the constitutional system in Indonesia, the implementation of outsourcing workers' employment relationship should be included in public domain, where the government should be totally involved and participates in it. However, entrepreneurs want it to be that employment issues should be a civil matter, thus, the government does not need to intervene too much with employment issues such as minimum wage determination, worker/labor protection, and so forth. According (16), On the other hand, workers, labor union and labor activists want employment matter to be a public issue, where the governmens definitely need to take a strategic role in employment issue, even though in certain aspects the matters at hand could be fully given to workers/labors and employers to decide (p. 43).

The position of workers/labors and employers is juridically equal before the law (equality before the law), yet, economically and socially speaking, their positions clearly will never be the same. Employment law has this objective of erasing relation inequality between employers and workers/labors, as suggested by Sinzheimer on employment relationship where he argues that the employer is the party who has more power than workers (as cited in (17)(p.3). Work contract is indeed made, where individual freedom exists therein. However, in reality this is all just meaningless term for in that work contract, workers' bargaining position remains low to improve the employment relationship as they desire it to be.

Workers are seeking jobs, and employers are giving jobs as well as owning capitals. Employers have more strengths than workers, leading to their higher and stronger bargaining position than that of workers. Such condition where workers have weaker, and even weakened, position would always remain. As the demand grows, the increasingly competitive global competition is undoubtedly inevitable. In business world, within which the roles and interrelatedness between workers and employers exist in their goods and service production processes, it is undeniable that there is a need for creating work certainty and stable business continuance by implementing a certain employment relationship in every company. Work certainty and business continuance need to be continuously built, developed and maintained by all components, making the government's (public authority's) roles and intervention still needed, unless if the bargaining position between workers and employers are balanced as what happens in several developed countries.

As stated by Birawan and Prasetyantoko (2004), "There is this highly strong consensus from private sector that the law and regulations on employment has sided more to workers at the costs of employers" (p.95). Employers think that workers/ labors have more control over the condition in Law Number 13 of 2003 concerning Employment, leading to an inbalanced rights and duties. Flexibility in employment relationship between workers and employers is, therefore, a demand which must be accomodated.

Structurally, the role that the government plays is highly critical to establish regulations which give protection to workers intactly and to implement and monitor in a committed and consistent manner. Despite the clarity in legal perspective, in practice it is then interpreted structurally differently, because it is based on interest and logic, rather than from worker/labor protection perspective based on the law. A good example of this is the interpretation of Articles 64-66 of Law Number 13 of 2003 concerning Employment. In relation to employment relationship, it is stated that a company may transfer some of their jobs to another company through a service supply scheme, or the supply of worker service made in writing and the workers/labors of the worker/labor service supplier must not be employed to carry out the main activities or the activities directly related to the production process, unless for supporting service activities or any activity with no direct relation with the production process. However, in its implementations workers from this worker supplier should do the main work in the principal company. This is clearly a deviation from article 66 . Therefore, for the sake of the law, the status of employment relationship between workers and worker/labor service supplier should shift into an employment relationship between workers and the principal company.

Law Number 13 of 2013 concerning employment has given justification to the partial transfer of job implementation to another company or worker/labor service supplier, or commonly known as outsourcing. This outsourcing system belongs to an employment relationship based on employment loan agreement (oitzendverhouding).

\section{Research Methodology}

This research uses the paradigm of constructivism which is based on philosophical and methodological aspects, including such dimensions as: firstly, ontologic dimension, i.e. reality is a social construction and the truth of a reality is relative in nature, applicable according to the specific context which is deemed relevant by social agents. Secondly, epistemologic dimension, i.e. transactional/subjective regarding the understanding of a reality or research findings are products of interaction between the one researching and the one subjected to that research. Thirdly, 
methodologic dimension, i.e. emphasizing on empathy and interaction of dialectics between the researcher and respondents to describe the reality being studied through a qualitative method. The method used in the research is quantitative, with sosio-legal research approach. Sosio-legal research approach reviews the law using law and social sciences. This approach does not view legal institution as a normative, esoteric entity. Rather, it views it as a part of a social system in its entirety existing in an interrelated state with other social variables. This research emphasizes on making a description of social and legal reality, as well endeavouring to understand and explain the interrelatedness logically between them.

\section{Results And Findings}

\subsection{The State's Role in Fulfilling the Citizen Rights Related to Outsourcing Workers/Labors}

\subsection{In Developing Countries Such As Indonesia}

It is quite often that regulations of law are made as a political instrument for the government or the ruling elit which is an integral part of politic, law and power. Politic wants that the power could be used to govern the life that people are sharing. According to (18), that power, however, is usually embodied in various forms of regulations of law (p.14). The dominant influence of a political power will eventually determine the formed legal character. As stated by (19), from this, one could then tell which political power is the dominant one (p.142).

In relation to the law function as a social engineering tool, the role that the political ruler plays has significant influence on the law. The legal politic concept is a state policy in the field of politic, where its formulation is performed by those authorized in one certain political system. According to David Easton (as cited in Siahaan, 1984, p.15), those involved include customary leaders, tribe leaders, executive, legislators, judges, administrators, monarchy and so forth. This state police in the field of law include: (1) Policy, should be more of an action towards goals, rather than a behavior or action of random and accidental nature. It is therefore a planned action. (2) Policy, in essence consists of interrelated actions in some pattern moving towards certain goals taken by government officials, rather than stand-alone decisions (3) Policy, should deal with what is actually needed in the society, rather than just what an individual or certain group wants. (20) has further asserted :

"The enforcement and existence of employment law is highly strategic and fundamental. This is because its content incorporates not just technical issues of employment, but is also full with socio-economic and political contents which are also related to human rights issues" (p. 4).

Another factor which influences law in addition to the ruling elit's political interest is economic political rulers with their significant influence over the employment law. The government should have a catalyst function, i.e. capable of empowering the society, making efforts to drive it, being eager to compete, constantly missionoriented, prioritizing results rather than method or process, possessing entrepreneurship and always being anticipative or making efforts to prevent problems from occuring, of decentralized and market-oriented nature $(21)$

In trading globalization era, the government is challenged to play their role in implementing employment policies which can accomodate all interests from both the capitalists, workers/labors and the government themselves. This role that the government plays should at least has an impact in the arrangement of employment relationship between employers and workers/labors. According to(22)(p. 215), the assessment of an impact is to predict whether a policy intervention results in the desired effects or not Such a prediction does not produce the exact answers, and only several answers may be making sense. The objective of impact assessment is to predict the "net effects" of a policy intervention, i.e. the prediction of intervention's impact which is not interfered with influences from any process and event which may also influence the behavior or condiction targeted by the program under evaluation. The methods that can be used are as follows (23)( p.14) :

1) Comparing the problem/situation/condition with what happens before the policy intervention;

2) Conducting an experiment to test the impact of a program on an area or group by comparing it with what happen in other areas or groups which has not been subjected to intervention;

3) Comparing the costs and benefits achieved as a result/failure of policy intervention;

4) Using a model to understand and explain what is happening as a result of policies in the past;

5) Qualitative and judgemental approach to evaluate the success/failure of a policy and a program;

6) Using performance measurement to evaluate whether the objective or target has been achieved.

Assessing the impact of a policy program on the employment relationship of outsourcing workers/labors requires the review of meaning and idea of employment relationship of outsourcing workers/labors itself. The analysis of state policy effect may be contingent, depending on where the assessor differs.

(24) has further asserted :

"There are two laws to explain the variations in analysis of policy effects. The first law says that if research is conducted by the party which implements the policy, then the research results will show that the policies being implemented have produced good results. The second law suggests that research conducted by an independent analyst will show negative effects" (p.132).

The widespread impacts of outsourcing system are: it does not give the job term certainty, it lacks welfare and occupational protection for workers/labors, it has no compensation when their employment is terminated, much of their earnings would be cut by the outsourcing company, a social stratification in a commpany will appear, workers/labors would be discriminated against their age and marital status and contracted workers will find it hard to have a career. This is because some outsourcing companies do not completely implement the law. It is where the government should pay attention to. Also, the society is less informed of it, making it easy for certain parties to misuse it.

\subsection{Dealing with Impacts of Outsourcing Worker/Labor Employment Relationship Digression}

The economic demand of free market in globalization era will have some influence on the implementation of employment law in Indonesia. Such condition highly requires a government policy to apply worker/labor use-based economic growth. Results of International Labor Organization's (ILO) study (as cited in ILO, 2004, p.9) consistently propose an argumentation that the government needs to include the use of labor-based production method rather than 'equipment-based' production method in their public investment policy. In addition, the policy to create productive and immediate job vacancies has been one pillar of Decent Work Agenda (DWA). Free trading is believed to have negative impacts, particularly on the poor, including: (a) Significantly reduced labor wage. Since company has to reduce their costs, labors will be subject to extortion; (b) Decreased rural economy for losing in competition with international agricultural products; (c) Increased urbanization to major cities; (d) Increased number of informal sectors unprotected by the law; (e) More threatened environment, because trading will increase demand which eventually leads to increased natural resources exploitation. (25) has further asserted:

"In free market economy, low wage policy and soft implementation of regulations of law, including containment of 
labor fundamental rights will in fact be a factor to stand in the way of free market. The free market economic model is precisely driving greater autonomy to discuss collectively both to workers/labors and employers. The freedom owned by workers/labors and employers grows even bigger to discuss wage rate, work requirements and other work conditions" (p.13-28).

Globalization era has brought an impact on the role played by the government in providing protection to workers/labors through protective regulations because they are regarded as an obstacle to market economy, to woek with the actual market law. On the other hand, the Government should also give workplace protection to workers/labors. In relation to workers/labors and employers, the government applies free market economy, yet many protections and interventions are made by the government. This dualism of Indonesia's economic system, between people's economic system under Article 33 of 1945 Indonesian Constitution and liberal economic system based on KUHD (Commercial Code or Wetboek van Koophandel) has brought about a consequence that the economy should be organized based on market mechanism and it should be monitored with government control in order to prevent any reduction of social function. The market mechanism demands that the social function could remain working and some matters need to be intervened by the government using directed affirmative action, thus in using the market mechanism some social function will remain working, e.g. an intervention is made by the government through taxation, property and revenue distribution instrument, social security and labor system.

This affirmative action is addressed more to commoners, rather than the conglomerates. Choosing to use a market mechanism expected to be more efficient than the guided economy, the role that the government play can trigger economic growth which will be replaced by the private sector. According to (26), the choice of a market economy system should consider its weaknesses, namely of (a) the private sector is very sensitive to "future expectation toward risk" which can be quickly changing; and (b) the market economy is insensitive to sense of economic justice, the size of which may differ from sense of social justice (p. 5). The facts about the condition of the worker/ labors market which does not support the improvement in workers/labors' bargaining position against employers. The demands of market mechanisms on flexible work systems should be responded to by the government by setting clear limitations, so that the worker/labor's most important interests, i.e. social welfare and social security, will not be neglected. These social welfare and social security include wage systems that provide a decent living insurance for workers/labors such as wage base, overtime and so forth. On the social security side there is a need for protection system in the form of health insurance, severance pay and old age benefits for workers/labors.

Discrimination in employment relationship can be seen from the rules that prohibit wage policy based on male and female sex. It is also prohibited to employ workers / labors on the basis of differences in race, groups, and belief. Under Article 2 of Law No. 14 of 1969 concerning Main Provisions on Employment, it is stated that in applying the law and its implementation regulations no discrimination should be allowed. In Law No. 13 of 2003, it can also be found the prohibition of discrimination in onsiderationg "Whereas protection to workers/labors is intended to ensure their rights and to guarantee equal chances as well as treatment with no discrimination on whatsoever basis to realize workers/labors and their family's welfare".

According to (14), "The implementation of law in the field of employment cannot be separated from the fact that Indonesia is bound by such organization as ILO. Several ILO conventions have been acknowledged for its enforceability through its ratification in the national regulations of law" (p. 108). ILO can also be said to serve as a normative basis for the role that the state plays in employment issues through affirmative action. The ratification means that Indonesia acknowledges that ILO convention as a legal device of equal position as the law. This commitment in the relevant country is realized in an enforcement of regulations with legal sanctions for any parties related to employment, namely government, workers/labors and employers. Unfortunately, Indonesia ratified the ILO conventions "merely" in consideration of the insistence from ILO which continuously campaign it, rather than doing so as a step to implement the consequence of such convention ratification. This is the sanction for any country which had ratified the convention, yet deliberately denied it will have to face due to their political change. Indonesian government has frequently been under fire due to its poor employment law implementation.

\subsection{Employee Stock Ownership Programme as a Means for Harmonious Employment Relationship towards Worker/Labor Welfare}

Employment relationship between workers/labors and employers should only occur if they have a balanced bargaining power. Recognition of the existence of labor unions as an embodiment of workers/labors' rights is a balancing tool for employer's position who economically is higher than workers. Optimizing the implementation of democratization at work, where employment participation as a pillar of cooperation relationships between employers and workers/labors is placed in key positions in making partnership of cooperation relationships between workers/labors and employers. The relationship between workers/labors and employers in essence is an interdependent relationship, rather than conflict relationship, of personal nature. This is despite the sociologically weaker worker/labor position than the socioeconomic status of employers. Also, from the legal perspective, the relationship is a litle bit tilted. Cooperation relationship between workers/labors and employers in factual manner could be seen in the form of participation made by workers/labors.

Building the freedom of association which can realize a harmonious employment relationship and improve worker/labor welfare is not just giving a false hope. There are several forms of worker/labor participation at corporate level: (a) worker/labor participation as reflected in their taking part in determining wage, work requirements and other work conditions through collective discussion; (b) worker/labor participation as reflected from their taking part in determining company's policies of managerial nature through Work Council or Board of Directors; (c) worker/labor participation as reflected from their taking part in company stock ownership through employee stock ownership programme.

Those forms of participation are all means to improve cooperation relationship between employers and workers/labors through cooperation in establishing provisions on wage, work requirements and other work conditions, which will be included in an employment agreement. This way both workers/labors and employers will gain objective provisions. It will create a legal certainty at work, which in turn could improve workers' passion to work. Later on, the parties could determine a clause in the work agreement which prohibits both workers and employers from using lock-out mechanism related to the implementation of provisions as set forth in the work agreement.

Under such circumstance, there is a need for reconstruction of employment relationship based on just values which could create a harmonious employment relationship and improved just worker/labor welfare. According to (27), employee stock ownership belongs to the company's internal affairs, thus workers would make the efforts necessary to improve the company's progress in order for the company to gain the greatest possible profits. The sense of owning and responsible for the company from these workers/labors will get bigger, because they are owners of the company they are working for (p. 448), 


\section{Conclusion}

1 The state's presence which is initially expected to be able to give some assurance of protection of worker/labor basic rights creates repressive and exploitative impression against the worker/labor's interest. Meanwhile, the state role in industrial relationship seems to be more facilitative and accomodative for the capitalist interest. According to(28), Legal protection for workers/labors in outsourcing problems could not yet be settled by the state. Until recently, no adequate regulation has been made in regard to outsourcing with financial capitalism hegemony operating through "dis-solution subject" which does not view workers/labors as subjects of production worth any protection, rather they are just exploitable objects (p. 2).

2 Labor's efforts against this outsourcing system and contract labor are made by making demands to eradicate outsourcing system and contract labor which has been filed to the Constitutional Court. The order of Constitutional Court Number 27/PUU IX/2011 gives a legal consequence in the employment relationship under an outsourcing system, where a work agreement being made should give a transfer of protection, thus, when a change occurs to the existing outsourcing company to the new one, outsourcing workers/labors would not lose the job as long as the work agreement between the new outsourcing company and the employers remain valid. However, the Order of Judge Panel of Constitutional Court on Employment Agreement for Specified Time (Perjanjian Kerja Waktu Tertentu/ PKWT) does not include any requirements for transfer of protection of rights for outsourcing workers/labors whose work object remains valid in the said agreement. Therefore, it does not have binding legal power.

\section{References}

[1] Mol MJ. Outsourcing: design, process and performance: Cambridge University Press; 2007.

[2] Bartkus EV, Jurevičius V. Production outsourcing in the international market. Engineering Economics. 2007;51(1).

[3] Deni D. Outsourcing, Paper Outsourcing Final. PPM Riset Manajemen: Academia.edu; 2008. Available from: http://independent.academia.edu/dendeni.

[4] Suhardi G. Perlindungan Hukum Bagi Para Pekerja Kontrak Outsourcing: Universitas Atma Jaya Yogyakarta; 2006.

[5] Globerman S, Vining AR. The outsourcing decision: A strategic framework. Global outsourcing strategies: An international reference on effective outsourcing relationships. 2006:49-64.

[6] Rusli H. Hukum ketenagakerjaan, 2003: Ghalia Indonesia; 2004.

[7] Asikin Z. Dasar-Dasar Perburuhan (Foundations of Labor Affairs) In: Persad JRG, editor. 1993.

[8] Tambusai M. Pelaksanaan Outsourcing Ditinjau dari Aspek Hukum Ketenagakerjaan Tidak Mengaburkan Huhungan Indusirial. dalam Informasi Hukum. 2006;1.

[9] Marbun S, MD MM. Pokok-pokok hukum administrasi negara: Liberty; 1987.

[10] Beaumont N, Sohal A. Outsourcing in australia. International Journal of Operations \& Production Management. 2004;24(7):688700 .

[11] Kusuma RMAB. Negara Kesejahteraan dan Jaminan Sosial (Welfare State and Social Security). . Jurnal Konstitusi, B,160 2006;3.

[12] Friedmann W. state and the rule of law in a mixed economy. 1971.

[13] de Sousa Santos B. Toward a New Common Sense Law, Science and Politics in the Paradigmatic Transition. 1995.

[14] Bhakti Y. Hukum Internasional: Bunga Rampai. Bandung: Alumni; 2003.

[15] Rajagukguk HP. Peran serta pekerja dalam pengelolaan perusahaan: co-determination: Yayasan Obor Indonesia; 2002.

[16] Hakim A. Aspek Hukum Penyelesaian Perselisihan Hubungan Industrial. PT Citra Aditya Bakti, Bandung; 2010.

[17] Wedderburn L. Collective bargaining or legal enactment: the 1999 act and union recognition. Industrial Law Journal. 2000;29(1):1-42.

[18] Siahaan I. Politik Dalam Pespektif Hukum (Politic in Legal Perspective): Jakarta: Ind Hill Co; 1984.
[19] Juliantara D. Mahkota Penindasan Catatan Atas kebijakan Ketenagakerjaan (Oppresion Crown: A Note of Employment Policy). Jurnal WACANA. 2000; IV(142).

[20] Nasution BJ. Hukum ketenagakerjaan: kebebasan berserikat bagi pekerja: Mandar Maju; 2004.

[21] Keban YT. Enam Dimensi Strategis Administrasi Publik: Konsep, Teori dan Isu. 2014.

[22] Rossi PH, Lipsey MW, Freeman HE. Evaluation: A systematic approach: Sage publications; 2003.

[23] Parsons W. Public policy: pengantar teori dan praktik analisis kebijakan. Kencana Jakarta. 2005.

[24] Wilson JQ. Political organizations: Princeton University Press; 1974.

[25] Uwiyono A. Implikasi Hukum Pasar Bebas dalam Kerangka AFTA Terhadap Hukum Ketenagakerjaan di Indonesia”. Jurnal Hukum Bisnis. 2003;22.

[26] Benu F. Ekonomi Kerakyatan dan Pemberdayaan Ekonomi Rakyat: Suatu Kajian Konseptual. Ruang Ekonomi Kerakyatan Indonesia Th I-No. 2002.

[27] Sloane AA, Witney F. Labor relations: Prentice Hall; 2007.

[28] Royen UI. Perlindungan Hukum Terhadap Pekerja/Buruh Outsourcing (Studi Kasus Di Kabupaten Ketapang): UNIVERSITAS DIPONEGORO; 2009. 